\title{
PEMBENAHAN
}

\section{HALAMAN KANTOR}

KELURAHAN

BONTOTANGGA

KEC.TAMALATEA

Oleh :

ALFIRA SAHAR

19203770410002

\section{Alfira.sahar0505@gmail.com}

\section{Bentuk kegiatan}

Pembenahan halaman kantor lurah bonto tangnga

\section{Lokasi}

Kantor lurah Bonto Tangnga

Kec.Tamalatea

\section{Hari/Tanggal dan Waktu}

kamis, 22 Oktober 2020 pukul 10:00

\section{Peserta yang dilibatkan}

Mahasiswa KKLP

\section{Alasan diadakannya}

Setelah observasi lapangan, kami melihat pekarangan di kantor tersebut sangatlah gersang maka dari itu kami berinisiatif untuk mengadakan proker ini

\section{Tujuan dan Manfaat}

Kami mengadakan proker ini agar pekarangan kantor lurah bonto tangnga jauh lebih asri dari yang sebelumnya

\section{Deskripsi kegiatan}

Proses pembenahan halaman kantor lurah ini di lakukan selama beberapa hari . pembenahan ini di lakukan agar halaman kantor lurah jauh lebih asri dari yang sebelumnya. 